J. Lake Sci.(湖泊科学), 2008, 20(6): 705-714

http://www.jlakes.org. E-mail: jlakes@niglas.ac.cn

(C)2008 by Journal of Lake Sciences

\title{
东营凹陷古近系古湖盆演化与水化学场响应*
}

陈中红, 查 明, 刘太勋

(中国石油大学(华东)地球资源与信息学院, 东营 257061)

摘 要: 东营凹陷古近系水化学场分布与湖盆演化有着良好的对应关系, 以 $\mathrm{CaCl}_{2}$ 水型为主的高矿化度地层水是东营凹陷古近系 咸化湖盆的典型响应特征, 矿化度从深到逐渐降低, 体现出从咸化湖盆向微咸化湖盆及淡水湖盆演化的地球化学响应. 剖面上可 以划分为四种水文环境: 强开放性水文流畅带(地表到 $1.1 \mathrm{~km}) 、$ 弱开放性水文流畅带 $(1.1-2.0 \mathrm{~km})$ 、水文阻滞过渡带 $(2.0-2.5 \mathrm{~km})$ 和 封闭性水文迟缓带 $(2.5 \mathrm{~km}$ 以下), 水化学剖面的分带性与压力分布有着良好的对应关系. 东营凹陷古近系水化学场经历了早期的 沉积与淋滤的交替和新生代的埋藏封闭作用期, 其中在东营运动时期古近系水化学场表现最为活跃, 是深层卤水咸化地表浅层 淡水从而使浅层出现高矿化度地层水的关键作用期, 断裂的沟通起了重要作用, 显示出断陷湖盆的典型特征.

关键词: 地层水化学场; 矿化度; 油气成藏; 断陷湖盆; 东营凹陷

\section{Response and evolution of formation water chemical fields of the paleogene in Dongying sag}

\author{
CHEN Zhonghong, ZHA Ming \& LIU Taixun \\ (College of Georesources and Information, China University of Petroleum, Dongying 257061, P.R.China)
}

\begin{abstract}
The formation of water chemical characteristics in the Paleogene System had good response to the sedimentary conditions and its evolution in Dongying sag. The type of $\mathrm{CaCl}_{2}$ formation water with high salinity was representative response of the brine lake of the Paleogene System in Dongying sag. The content of total salinity and chloride ion decreased from the deep depth to the lower, which was good response to the evolution of the Dongying sag from salted basin to freshwater basin. According to the vertical characteristics of the underground water formation, four hydrological environments can be classified: stronger formation water frequency alternation belt $(0-1.1 \mathrm{~km})$, feeble formation water frequency alternation belt $(1.1-2.0 \mathrm{~km})$, formation water alternate blocking belt $(2.0-2.5 \mathrm{~km})$ and formation water alternate tardy belt $(>2.5 \mathrm{~km})$. In every belt the total salinity, ions and ion composition ratio had different responses, and the belts corresponded to the distribution of formation pressure. The formation water chemical field experienced deposition and leaching in early time and burial in later time. In the period of Dongying Movement the formation water chemical field was active, and salted water from the Member 4 of Shahejie Formation migrated to the lower, and in the course the faults played important roles, which demonstrated the representative characteristics of faulted basin.
\end{abstract}

Keywords: Formation water chemical field; oil accumulation; salinity; faulted basin; Dongying sag

地层水以不同的形式与油气共存于地下岩石孔隙空间中，作为油气运移、聚集的载体，它和油气之 间存在着经常性的物质成分交换, 其形成及其运动规律与油气成藏的形成、保存和破坏有着十分密切的 联系. 目前对地层水性质的研究根据矿化度、各种组成离子及相关比例参数，也有学者采用 $\mathrm{H} 、 \mathrm{O}$ 同位素 组成、 ${ }^{87} \mathrm{Sr} /{ }^{86} \mathrm{Sr}$ 等来分析地层水成因、沉积环境及油气聚集、保存条件等, 研究结果认为, 不同类型地层 水的成因、机制十分复杂，同生沉积作用、大气降水的侵人作用、蒸发浓缩作用及成岩变质作用等都会 对地层水的性质起改造作用，同时认为地层水化学场分布体现出盆地内能量场控制下的流体运移和聚集

* 山东省自然科学基金(Q2007E04)资助. 2007-11-05 收稿; 2008-05-21 收修改稿. 陈中红, 男, 1976年生, 博士, 讲师; E-mail: hongczh@163.com. 
的物质效应, 地层水化学场的研究可指示油气成藏的环境和水动力条件 ${ }^{[1-6]}$. 在国内, 也针对不同盆地水 化学场特征及其油气成藏意义开展了分析 ${ }^{[7-10]}$. 但目前此领域的研究多是有关单一盆地的水化学场响特 征, 对于湖盆演化与水化学场响应特征很少见有报道.

东营凹陷作为中国东部陆相断陷湖盆的典型代表, 其古近系湖盆经历了从咸水湖相、微咸水湖相、 淡水湖相、河流一三角洲相一个典型的沉积旋回, 其水化学场相应经历了相应的演化过程. 本文对东营 凹陷古近系水化学场进行研究, 可了解陆相断陷咸化湖盆地层水化学场对湖盆演化的响应特征及其油气 成藏意义, 具有十分重要的理论意义和实践意义. 为考察东营凹陷地层水化学场响应及与油气聚集关系, 从中石化胜利油田有限公司收集了东营凹陷古近系试油资料 1779 条数据体. 由于矿化度对地层水的化 学性质起着主导作用, 因此研究方法主要依据矿化度、氯离子、水型等主要参数, 并结合䥻离子、钠离 子、镁离子、碳酸(氢)根离子、硫酸根离子等其它离子变化特征, 同时参照离子组合系数进行判断. 运用 的离子组合系数有变质系数 $\left(\mathrm{rNa}^{+} / \mathrm{rCl}^{-}\right)$、氯镁系数 $\left(\mathrm{rCl}^{-} / \mathrm{rMg}^{2+}\right)$ 、脱硫系数 $\left(\mathrm{rSO}_{4}{ }^{2-} \times 100 / \mathrm{rCl}\right)$ 、碳酸盐平衡系 数 $\left(\left[\mathrm{rHCO}_{3}{ }^{-}+\mathrm{rCO}_{3}{ }^{2-}\right] / \mathrm{rCl}^{-}\right)$.

\section{1 区域概况}

东营凹陷属于渤海湾中、新生代裂谷盆地的三级负向构造单元，位于济阳坳陷南部，具有北断南超 的开阔型箕状凹陷特征. 该凹陷是在古生界基岩古地形背景上经构造运动发育起来的断陷-㘬陷湖盆, 面 积 $5700 \mathrm{~km}^{2}$. 凹陷内断层十分发育. 重要的正向二级构造带主要有陡坡断裂构造带, 缓坡断裂构造带, 陡 坡、缓坡超覆带, 断裂背斜构造带, 断裂鼻状构造带和潜山披覆构造带. 重要的负向二级构造带有利津洼 陷、牛庄洼陷、博兴洼陷、民丰洼陷，负向洼陷之间被正向构造带断裂所切割(图1).

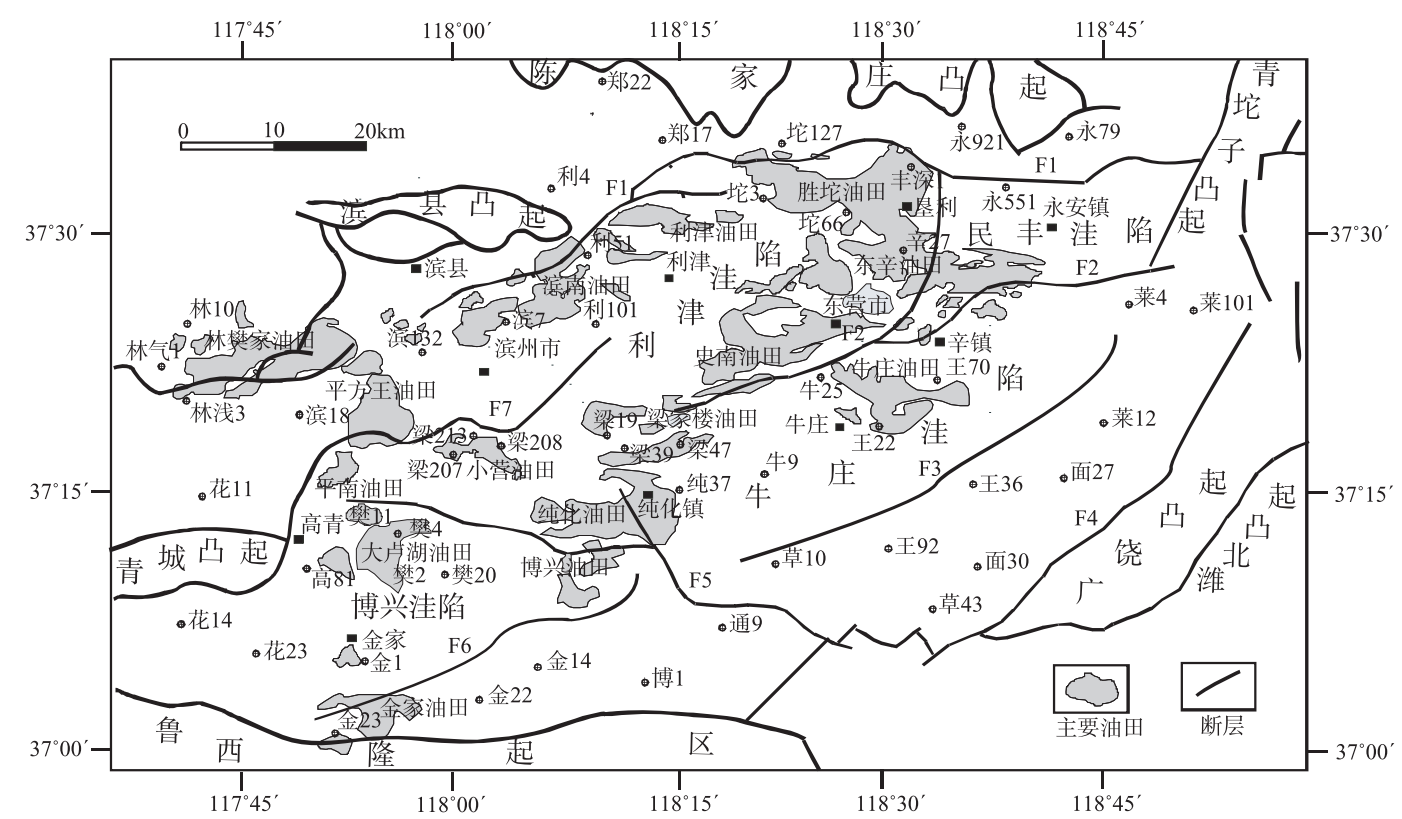

图 1 东营凹陷区域构造地质概况图

(F1: 永胜断裂带; F2: 梁家楼-现河断裂带; F3: 陈家庄-王家岗断裂带; F4: 八面河断裂带;

F5: 纯化-乐安断裂带; F6: 博兴断裂带; F7: 平南-高青断裂带)

Fig.1 A simplified map showing structural characteristics of the Dongying sag

受北部边界陈南大断裂的控制, 古近系沉积了一套以泥质为主夹砂岩、碳酸盐岩的碎屑物质. 在构 造运动的控制下，该段沉积物经历了盐湖相、深湖相及河流一三角洲相旋回式沉积过程，其中孔店组、沙 
四段为蒸发环境下的盐湖沉积, 沙三段主要发育大套暗色泥岩夹油页岩、薄层砂岩的半深湖、深湖、浅 湖相沉积, 沙二段为砂泥岩互层的河流一三角洲相沉积, 沙一段到东营组为下一旋回的湖相沉积, 发育 灰色、灰褐色泥岩. 其中暗色泥岩主要发育于沙四段上亚段、沙河街组三段下亚段和沙三段中亚段, 它 们构成了东营凹陷的主力烃源岩. 勘探实践表明, 东营凹陷古近系深层沙四下和孔店组也具有一定的生 烃潜力. 近几年的试油结果显示, 北部陡坡带多口井在沙四下亚段获得高产工业裂解气流，而王46井揭 示孔二段烃源岩亦具有较好的生烃指标显示, 而且目前在东营凹陷古近系的各层系(从下向上)孔店组、沙 四段、沙三段、沙二段、沙一段、东营组都发现了油、气藏, 因此东营凹陷古近系是胜利油田重要的目 标层系, 在油气勘探中具有重要地位.

\section{2 湖盆演化及水化学场响应}

\section{1 初始裂陷期——咸水湖相沉积期}

东营盆地古近系经历了裂陷初期(始新世孔店组及沙四段沉积期)、深陷扩张期(沙三段沉积期)、抬升 收缩期 (沙二段至东营沉积末期 $)^{[11]}$. 以早第三纪各裂陷期末形成的不整合面为界, 古近系一级构造层序 可划分为 3 个二级构造层序，即孔店组、沙四段至沙二段及沙一段至东营组，分别对应于 3 个亚裂谷旋回， 其中沙四段至沙二段为湖盆发育主旋回层 ${ }^{[12]}$.

东营凹陷孔店组-沙四段沉积时期为湖盆的初始裂陷期，即相当于裂谷盆地的形成期(孔店早期至沙 四末期). 在孔店组沉积期时, 处于构造转型期, 受郯庐断裂带的影响, 凹陷由中生代的左旋平移运动向 古近纪的右旋平移运动转换, 作用强度大, 运动状态由南向北、由东向西迁移，东营凹陷孔店期及其以后 具有相同的沉降中心, 具红色冲积扇一河流为主的盆地充填特征 ${ }^{[1]}$. 孔店早、中期沉积时, 东营湖盆处于 烈陷初期, 湖盆开始下陷, 水体开始变深. 洼陷区由于沉积物供给不足, 主要为滨浅湖沉积环境, 但由于 气候比较干旱, 阳光充足, 蒸发作用强烈, 在湖盆北部发育盐湖或盐滩沉积, 形成亳盐层, 导致盐度增加, 相应地在盆地北部中央背斜带的东风 5 井处, 表现为超高矿化度(达到 $326.7 \mathrm{~g} / \mathrm{L}$ ), 王家岗油田的王 96 井 孔店组也显示高矿化度(约为 $103.8 \mathrm{~g} / \mathrm{L}$ ). 从湖盆中心向湖盆边缘, 冲积扇沉积及河流作用频繁, 地下水的 淋滤作用增强, 导致矿化度偏低, 如处于博兴断裂阶状构造带柳 4 井孔店组矿化度仅 $0.48 \mathrm{~g} / \mathrm{L}$, 处草桥鼻 状构造的草 19 井矿化度约 $8.8 \mathrm{~g} / \mathrm{L}$, 显示了不利的油气保存环境. 该层矿化度和氯离子含量平均值分别为 $60.6 \mathrm{~g} / \mathrm{L} 、 35.68 \mathrm{~g} / \mathrm{L}$. 绝大多数以 $\mathrm{CaCl}_{2}$ 水型为主, $\mathrm{NaHCO}_{3}$ 水型为次要水型, 主要发育于高青一平南断裂构 造带和尚店一平方王潜山披覆构造带, 极少数的 $\mathrm{Na}_{2} \mathrm{SO}_{4}$ 水型(占样本数的 3.9\%)显示于鲁西隆起的金浅 6 和金浅 2 井, 反映开放性的氧化性水文环境, 没有发现 $\mathrm{MgCl}_{2}$ 水型.

沙四下段沉积时，盆地裂陷作用加强，构造沉降幅度开始加大，气候仍然保持干旱，气候干热并向 盐湖演化, 主要为石膏、岩盐沉积, 湖水含盐度很高, 化学沉积比较发育, 后期形成了以灰色泥岩夹石 膏、盐岩为主的地层, 在凹陷的中心部位形成了厚达 400-600m 的盐岩、石膏层, 湖相碳酸盐岩沉积体系 广泛发育 ${ }^{[12]}$. 沙四中下段矿化度和氯离子较孔店组稍有增大, 矿化度和氯离子平均含量分别为 $63.3 \mathrm{~g} / \mathrm{L}$ 和 $37.84 \mathrm{~g} / \mathrm{L}$. 矿化度高值中心 $(>100 \mathrm{~g} / \mathrm{L})$ 分布于盆地北部陡坡带附近民丰洼陷，在民丰洼陷丰 8 井处，矿化 度显示最高值 $(355.5 \mathrm{~g} / \mathrm{L})$. 矿化度等值线具有一定的对称性, 对称轴线沿东北-西南方向延伸, 从湖盆边缘 向中心, 矿化度依次升高. $\mathrm{CaCl}_{2}$ 水型比例降低(占样本数的 $80.4 \%$ ), $\mathrm{NaHCO}_{3}$ 水型所占比例升至 $20.7 \%$, 发 育极少数的 $\mathrm{Na}_{2} \mathrm{SO}_{4}$ 水型和 $\mathrm{MgCl}_{2}$ 水型.

沙四上段沉积期, 盆地下沉, 水域面积扩大, 沉积作用以碎屑沉积为主, 形成了以灰黑色页岩、油页岩、 泥岩为主的地层, 而洼陷中心地带以岩盐沉积为主 ${ }^{[2]}$. 沙四上段矿化度和氯离子总体较沙四中下段有所降 低, 矿化度、氯离子平均含量分别为 $54.2 \mathrm{~g} / \mathrm{L}$ 和 $31.83 \mathrm{~g} / \mathrm{L}$. 矿化度高值中心 $(>100 \mathrm{~g} / \mathrm{L})$ 分布于利津洼陷，与盐 岩沉积中心对应, 在利津洼陷利 88 井处, 矿化度显示最高值 $(289.9 \mathrm{~g} / \mathrm{L})$. 在洼陷内部, 随着埋深的增加, 地 表水下渗强度减弱, 同时淡化特征也减弱; 随地下水在下渗流动过程中溶解的溶质增多, 使矿化度和氯离 子的浓度逐渐增加, 在滨 48 井矿化度值达 $257 \mathrm{~g} / \mathrm{L}$, 官 112 井 $230 \mathrm{~g} / \mathrm{L}$, 在盆地边缘, 由于埋藏较浅、大气水 下渗数量大, 地下水淡化现象明显, 如单 13 井矿化度降低至约 $1.5 \mathrm{~g} / \mathrm{L}$, 而官 9 井约 $1.6 \mathrm{~g} / \mathrm{L}$. 该层段 $\mathrm{CaCl}_{2}$ 水 型比例升至 $80.4 \%, \mathrm{NaHCO}_{3}$ 水型所占比例降至 $12.5 \%, \mathrm{Na}_{2} \mathrm{SO}_{4}$ 水型和 $\mathrm{MgCl}_{2}$ 水型仍然占极少数. 
上述特征显示出咸化湖盆中高矿化度地层水化学场的响应特征. 由于在该沉积期，东营凹陷气候以 干旱-半干旱为主, 并且当时山势较高, 连绵分布, 高山之间为大型断陷湖盆, 气候干热, 造成湖盆水体 的大量蒸发, 使水体盐度升高, 湖泊咸化 ${ }^{[13]}$, 从而形成高矿化度型 $\mathrm{CaCl}_{2}$ 型地层水, 对应沉积物的特点为 碎屑岩-碳酸盐岩-硫酸岩组合类型，显示了湖盆的封闭性以及局部水体短暂的干化浓缩过程和半干旱的 蒸发环境 ${ }^{[14-15]}$, 这种封闭性咸化湖盆具备缺氧的强还原条件, 地层水活动十分微弱或完全停止而处于封 闭状态 ${ }^{[16]}$, 因此该时期地层水处于沉积作用和蒸发浓缩作用期.

\section{2 深陷扩张期——微咸水一淡水湖相沉积期}

沙三段是在断陷作用强烈、气候湿润、物源供给较充分的条件下沉积的. 沙三下亚段沉积时, 断裂 活动强烈, 盆地断陷作用增强, 可容空间较大, 此时东营凹陷的大部分地区处于深湖-半深湖环境 ${ }^{[17]}$. 这 种沉积环境中发育了深湖相油页岩、深灰色泥岩、钙质泥岩和深水浊积扇沉积，泥岩含量约占 $70 \%$ 以， 油气保存条件较为有利. 与此相应, 沙三下段矿化度和氯离子平均值显示为研究区古近系最高值, 其中 矿化度、氯离子含量平均值分别达 $64.8 \mathrm{~g} / \mathrm{L} 、 39.02 \mathrm{~g} / \mathrm{L}$. 矿化度高值中心 $(>100 \mathrm{~g} / \mathrm{L})$ 分布于盆地中央背斜带 的河 123 井 $(303.3 \mathrm{~g} / \mathrm{L})$ 和辛 136 井处 $(259.7 \mathrm{~g} / \mathrm{L})$, 分布于中央背斜带的营 73 、营 88 井、永 8 井和坨-胜-永 断裂构造带的坨 713 井、731 井、矿化度均高达 210-250g/L. 沿盆地边缘，矿化度降低，基本上都属于中 矿化度类型, 但是在南东和南西方向出现两个低值, 草 14 井矿化度为 $3.7 \mathrm{~g} / \mathrm{L}$ 、金 16 井矿化度为 $4.9 \mathrm{~g} / \mathrm{L}$. $\mathrm{CaCl}_{2}$ 水型占样本数的 $78.4 \%, \mathrm{NaHCO}_{3}$ 水型所占 $14.4 \%$, 发育少量 $\mathrm{Na}_{2} \mathrm{SO}_{4}$ 水型和 $\mathrm{MgCl}_{2}$ 水型 $\mathrm{Na}_{2} \mathrm{SO}_{4}$ 水型 显示于金 27 井、訤 24 、禁 25 井, $\mathrm{MgCl}_{2}$ 水型显示于牛 6 、明 6、坨 86 、单 13 等井).

沙三中亚段沉积时, 东营凹陷的水体明显变浅, 湖盆收缩, 深湖-半深湖面积减小, 以三角洲沉积为 主, 北部发育滨-浅湖相和三角洲相为主的开放性沉积体系, 东部三角洲也向凹陷内部推进, 形成了一套

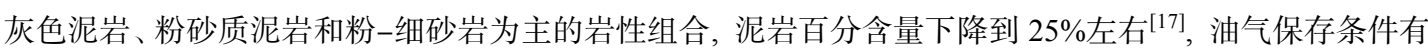
所减弱. 沙三中段矿化度、氯离子含量平均值分别为 $56.8 \mathrm{~g} / \mathrm{L} 、 32.72 \mathrm{~g} / \mathrm{L}$. 矿化度高值中心分布于盆地中 央背斜带的营 71 井 $(330.8 \mathrm{~g} / \mathrm{L})$ 和营 72 井处 $(325.9 \mathrm{~g} / \mathrm{L})$, 分布于中央背斜带的河 1 井、河 129 井和牛庄洼陷 的王 56 等井矿化度均高达 $250-300 \mathrm{~g} / \mathrm{L}$. 而沿盆地边缘, 矿化度变化幅度也较大, 矿化度从 $5-70 \mathrm{~g} / \mathrm{L}$, 低值 区分布于陈家庄-王家庄断裂阶状构造带的梁 24 井 $(9.6 \mathrm{~g} / \mathrm{L})$ 和金家鼻状构造带的金 21 井 $(5.7 \mathrm{~g} / \mathrm{L})$. 该层段 $\mathrm{CaCl}_{2}$ 水型比例较下部层段明显下降(占 $64.2 \%$ ), 而 $\mathrm{NaHCO}_{3}$ 水型显著上升，占总样本数的 $33.2 \%$, 少量 $\mathrm{MgCl}_{2}$ 水型显示于滨 119、青东 4、滨 134 、梁 65 井, 而 $\mathrm{Na}_{2} \mathrm{SO}_{4}$ 水型显示于营 1 和营 72 井.

沙三上亚段沉积时，东营凹陷水体继续变浅，河流三角洲占主导地位，油气保存环境变差. 沙三上 段矿化度、氯离子平均含量分别为 $54.2 \mathrm{~g} / \mathrm{L} 、 23.98 \mathrm{~g} / \mathrm{L}$. 矿化度高值中心分布于盆地牛庄-六户洼陷的王 56 井 $(289.4 \mathrm{~g} / \mathrm{L})$ 和中央背斜带的辛斜 149 井处 $(279.5 \mathrm{~g} / \mathrm{L})$. 矿化度低值区分布于博兴断裂阶状构造带的草 斜 107 井 $(3.16 \mathrm{~g} / \mathrm{L})$ 和草 112 井 $(3.91 \mathrm{~g} / \mathrm{L})$ ，处于金家鼻状构造带的金 7 井和金 9 井矿化度也较低，分别为 $3.46 、 3.81 \mathrm{~g} / \mathrm{L} . \mathrm{CaCl}_{2}$ 水型比例较下部层段继续下降(占 $62.4 \%$ ), $\mathrm{NaHCO}_{3}$ 水型升至 $34.6 \%$, 少数 $\mathrm{MgCl}_{2}$ 水型 (3\%)显示于滨 39、莱 17 、利 37 和滨 415 井, 未发现 $\mathrm{Na}_{2} \mathrm{SO}_{4}$ 水型.

该沉积期 $\mathrm{NaHCO}_{3}$ 水型样本比例较初始裂陷期升高，这是由于在始新世末，东营凹陷经历了一次弱 的构造抬升作用，使始新世沙四期与沙三期之间形成沉积间断，地表上的大气降水经过间断面下渗，使 不整合面附近的地层水明显淡化，并在不整合面附近形成低矿化度 $\mathrm{NaHCO}_{3}$ 型水，为淋滤作用期.

\section{3 抬升收缩期——淡水湖盆沉积期}

从沙三段到沙二段为一沉积旋回，此旋回中湖盆经历了沙三下段沉积期的发展、沙三中的鼎盛到沙 三上沉积期的萎缩及沙二段沉积期的消亡, 湖盆连续堆积了沉大量沉积物, 此时地层水处于沉积作用期.

沙二段沉积时，构造活动所造成的下陷已停止，可容纳空间由于沉积物的充填则逐渐减小，气候则 由潮湿转变为温湿. 沙二期末，东营凹陷再次抬升，遭受剥蚀，从而形成沙二段与沙一段之间的不整合 面，此时研究区再次处于淋滤作用期，由于沙二段沉积了较粗的沉积物，地表上的大气降水再次经过间 断面下渗，并深及沙二段内部，使沙二段、沙一段的地层水均遭淡化. 相应地，沙二段矿化度和氯离子含 量较下部层位明显降低，其平均值分别为 $33.6 \mathrm{~g} / \mathrm{L} 、 20.27 \mathrm{~g} / \mathrm{L}$. 矿化度高值中心分布于盆地中央背斜带的辛 38 井 $(162.9 \mathrm{~g} / \mathrm{L})$. 矿化度低值区分布于金家鼻状构造带的通 59 井 $(1.58 \mathrm{~g} / \mathrm{L})$ 和博兴断裂阶状构造带的草36井 
$(1.92 \mathrm{~g} / \mathrm{L}) . \mathrm{CaCl}_{2}$ 水型比例较沙三上部层段升高(占75.6\%), 而 $\mathrm{NaHCO}_{3}$ 水型较沙三上段下降 $21.3 \%$, 少量 $\mathrm{MgCl}_{2}$ 水型显示于滨 124 、牛27、利 58 、高36等多口井，而 $\mathrm{Na}_{2} \mathrm{SO}_{4}$ 水型仅显示于坨42井.

沙一段沉积时期，盆地再次发生低幅短期区域性沉降，气候温暖，洼陷带形成了以油页岩、暗色泥岩 为主的浅湖-半深湖相沉积. 沙一段矿化度、氯离子含量平均为 $20.9 \mathrm{~g} / \mathrm{L} 、 11.62 \mathrm{~g} / \mathrm{L}$. 矿化度高值中心分布 于滨南-利津断裂构造带的滨 650 井 $(132.8 \mathrm{~g} / \mathrm{L})$, 矿化度低值区分布于尚店-平方王潜山披覆构造带的滨 546 井 $\left(1.57 \mathrm{~g} / \mathrm{L}\right.$ ). $\mathrm{CaCl}_{2}$ 水型比例较沙一段下降(占 $68.4 \%$ ), $\mathrm{NaHCO}_{3}$ 水型升至 $25.7 \%, \mathrm{Na}_{2} \mathrm{SO}_{4}$ 水型和 $\mathrm{MgCl}_{2}$ 水型仍然占极少数(分别为 $1.6 \%$ 和 $4.3 \%$ ), 少数 $\mathrm{MgCl}_{2}$ 水型 $(3 \%)$ 显示于高 55 、营 34 、坨 90 和坨 32 等井, 而 $\mathrm{Na}_{2} \mathrm{SO}_{4}$ 水型显示于金 29、单 53 、金浅 8 井等盆地边缘地带.

沙一段到东营组形成沉积旋回，湖盆再次经历短暂的发展和萎缩的演化过程，此时地层水处于沉积 作用期.

东营期沉积时期，由于构造再次抬升，气候干燥，湖盆大面积收缩，湖水逐渐变浅，对油气保存条件 不利. 东营组矿化度分布于 $0.38-96.5 \mathrm{~g} / \mathrm{L}$, 平均值达 $17.7 \mathrm{~g} / \mathrm{L}$, 氯离子含量分布于 $0.047-58.17 \mathrm{~g} / \mathrm{L}$, 平均达 $10.48 \mathrm{~g} / \mathrm{L}$. 矿化度高值中心分布于尚店-平方王潜山披覆构造带的滨 170 井 $(96.5 \mathrm{~g} / \mathrm{L}) . \mathrm{CaCl}_{2} 、 \mathrm{NaHCO}_{3}$ 、 $\mathrm{Na}_{2} \mathrm{SO}_{4} 、 \mathrm{MgCl}_{2}$ 水型分别占样本数的 $64.6 \% 、 20.8 \% 、 4.2 \%$ 和 $10.4 \%$.

\section{4 东营运动及其后期}

渐新世末期发生的东营运动使东营凹陷整体抬升，在东营组之上形成一广泛的不整合面，使东营组 和沙一段大范围内受大气降水的深人而淡化，部分下渗水甚至影响到沙二、沙三段地层，不过此时东营 运动产生的大量张性正断层, 形成良好的运移通道, 沟通了沙四、沙三中下段封闭性超压水动力系统和 上部的开放性静水常压系统，使得沙四段盐湖中形成的高矿化度盐卤水及早期生成的烃类和伴生的 $\mathrm{CO}_{2}$ 气体等物质运移到浅层, 与上覆地层水发生混合, 导致上部地层中的地层水矿化度升高, 同时在沙三、沙 二、沙一等浅层中形成了部分较高矿化度的 $\mathrm{CaCl}_{2}$ 水型和 $\mathrm{NaHCO}_{3}$ 水型, 因此该时期应该为研究区地层水 最活跃的时期.

东营组沉积后, 由于东营运动的影响, 发生区域性拗陷, 使古近系地层进人埋藏封闭作用期, 此时 地层水的活动主要体现在水岩作用中的离子交换、半透膜的渗透作用和不同盐度地层水的混合作用上. 随着上覆地层的不断沉积, 古近系地层载荷增大, 压实作用增强, 加上东营运动产生的断层的沟通, 超 压地层中的泥岩中的地层水不断流向砂岩, 促进了各种地层水活动的进行, 从而形成了研究区如今复杂 的地层水化学场分布格局.

\section{5 水型分布平面响应特征}

从水型平面分布看, 在孔店组-沙四段咸化湖盆中, 研究区绝大部分都是 $\mathrm{CaCl}_{2}$ 水型, 仅在部分湖盆 边缘地带(金家、尚店、单家寺、王庄等地区)发育 $\mathrm{NaHCO}_{3}$ 水型，同时在津-滨南断裂构造带附近的滨南 油田、纯梁油田、单家寺油田发育 $\mathrm{Na}_{2} \mathrm{SO}_{4}$ 水型, $\mathrm{MgCl}_{2}$ 水型主要出现于平房王、尚店油田交界处. 在湖 盆发展到鼎盛期的沙三段, 研究区 $\mathrm{CaCl}_{2}$ 水型仍然占大多数, 但 $\mathrm{NaHCO}_{3}$ 水型也明显增多, 湖盆西部的利 津-滨南断裂构造带附近的滨南油田、梁家楼油田、利津油田都广泛发育 $\mathrm{NaHCO}_{3}$ 水型, 在这些地区同时 也见到少量的 $\mathrm{Na}_{2} \mathrm{SO}_{4}$ 水型, $\mathrm{MgCl}_{2}$ 水型主要出现于王庄油田南部; 在湖盆萎缩到消亡阶段的沙二段、沙 一段和东营组, 仍然以 $\mathrm{CaCl}_{2}$ 水型为主, $\mathrm{NaHCO}_{3}$ 水型发育于湖盆西北部的平房王-尚店断裂构造带和宁 海-利津一带, 少量的 $\mathrm{Na}_{2} \mathrm{SO}_{4}$ 水型分布于金家油田和单家寺油田，在湖盆东部发育少量 $\mathrm{MgCl}_{2}$ 水型.

由上可以看出, 东营凹陷古近系水化学场分布是湖盆演化的良好响应, 矿化度随湖盆演化逐渐减小, 也体现出从咸化湖盆向微咸化湖盆及淡水湖盆演化的地球化学响应(图 2). 各离子、水型及变质系数、氯 镁系数、脱硫系数及碳酸盐平衡系数等主要水化学参数也有着相应的地球化学响应(表 1、表 2).

\section{3 水化学场剖面分带性}

根据各种水化学参数在剖面分布的综合分析, 东营凹陷古近系水化学剖面宏观上具有一定的分带性, 大致可以划分为 4 种水文环境: 强开放性水文流畅带、弱开放性水文流畅带、水文阻滞过渡带和封闭性水 文迟缓带(图3). 

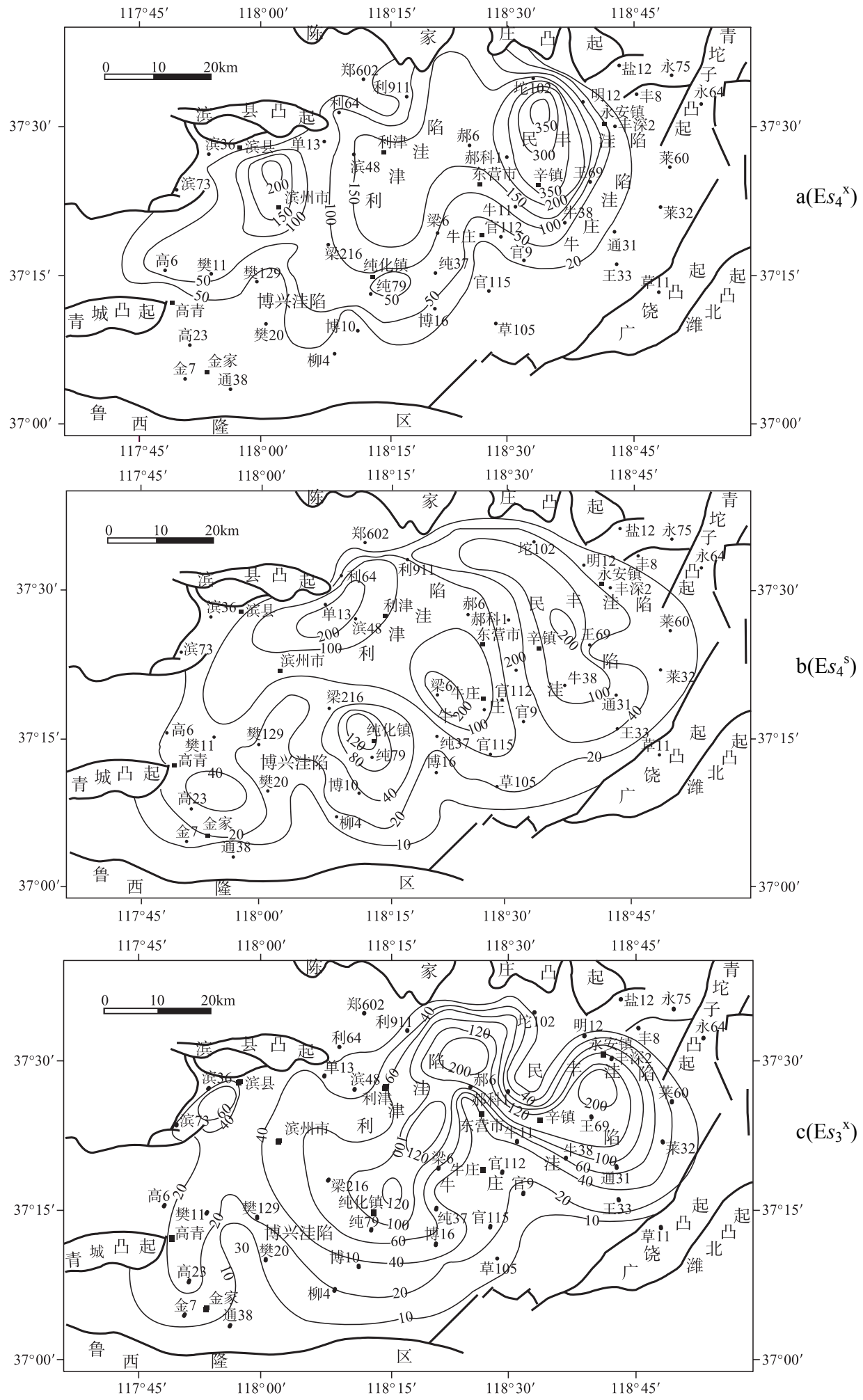

图 2 东营凹陷古近系矿化度平面分布

Fig.2 The distribution of total salinity in the Paleogene System in Dongying sag 

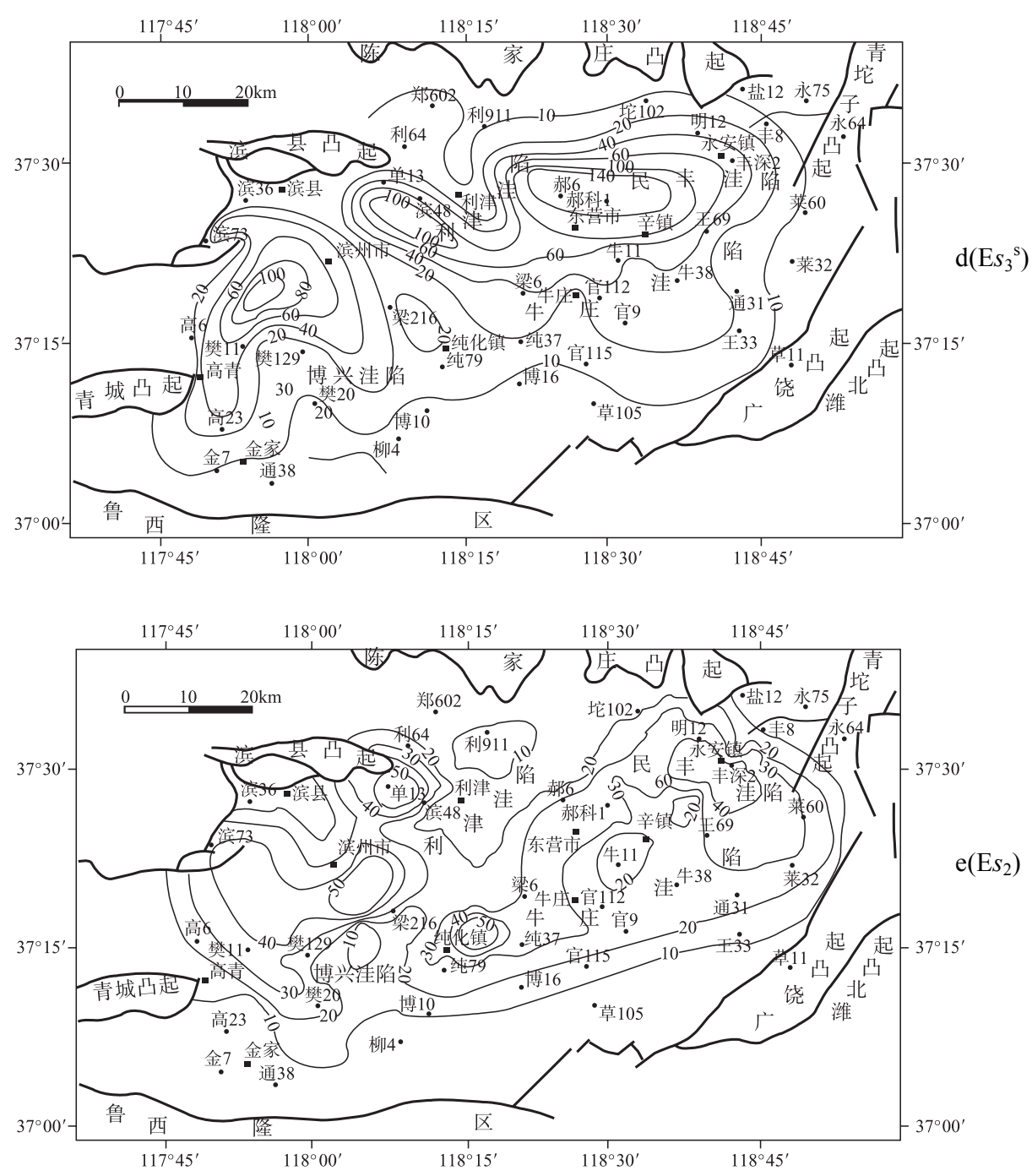

图 2(续) 东营凹陷古近系矿化度平面分布

Fig.2(Continued) The distribution of total salinity in the Paleogene System in Dongying sag

强开放性水文流畅带分布于地表到 $1.1 \mathrm{~km}$, 处于正常静水压力系统, 在该带矿化度以及各主要离子 含量均显示低值, 矿化度基本小于 $20 \mathrm{~g} / \mathrm{L}$, 钙离子、镁离子小于 $0.2 \mathrm{~g} / \mathrm{L}$, 碳酸氢根离子小于 $1.0 \mathrm{~g} / \mathrm{L}, \mathrm{NaHCO}_{3}$ 水型占绝对优势, 并发育部分 $\mathrm{Na}_{2} \mathrm{SO}_{4}$ 水型, 反映了该带受地表水活动的影响, 水交替活动强烈, 是油气 不利的保存环境, 流体运动主要表现为大气降水向心流方式.

从1.1-2.0km左右为弱开放性水文流畅带, 仍然处于正常静水压力系统, 在该带矿化度以及各主要离 子含量均保持相对缓慢增长趋势, 矿化度最高值从 $20 \mathrm{~g} / \mathrm{L}$ 升至 $100 \mathrm{~g} / \mathrm{L}$, 氯离子从 $10 \mathrm{~g} / \mathrm{L}$ 升至 $80 \mathrm{~g} / \mathrm{L}$, 镁离子 和钻离子从 $2.0 \mathrm{~g} / \mathrm{L}$ 分别升到 $10 \mathrm{~g} / \mathrm{L}$ 和 $1.0 \mathrm{~g} / \mathrm{L}$, 碳酸氢根离子从 $1.0 \mathrm{~g} / \mathrm{L}$ 升至 $3.0 \mathrm{~g} / \mathrm{L}$, 主要发育 $\mathrm{NaHCO}_{3}$ 水型和 $\mathrm{CaCl}_{2}$ 水型, $\mathrm{NaHCO}_{3}$ 水型稍占优势, 仍然发育少量 $\mathrm{Na}_{2} \mathrm{SO}_{4}$ 水型, 反映了该带仍然受地表水活动影响, 并且 随深度增加受地表水挥动影响减弱, 水交替活动也相对减弱, 向有利的油气保存环境方向转化.

2.0-2.5 $\mathrm{km}$ 是一种过渡的水文环境, 处于正常压力向超压系统的过渡地带, 称为水文阻滞过渡带. 在 该带矿化度最高值从 $100 \mathrm{~g} / \mathrm{L}$ 升至 $200 \mathrm{~g} / \mathrm{L}$ ，氯离子从 $10 \mathrm{~g} / \mathrm{L}$ 升至 $200 \mathrm{~g} / \mathrm{L} ，$ 镁离子和钙离子含量最高值均稳定 
保持在 $10 \mathrm{~g} / \mathrm{L}$ 和 $1.0 \mathrm{~g} / \mathrm{L}$, 钠离子含量从 $40 \mathrm{~g} / \mathrm{L}$ 上升到 $60 \mathrm{~g} / \mathrm{L}$, 以 $\mathrm{CaCl}_{2}$ 水型为主, 并发育部分 $\mathrm{NaHCO}_{3}$ 水型, 反 映了该带水交替活动已经大大减弱, 地层水活动处于一种相对阻滞状态, 是浅层开放性地层水系统相深 层封闭性水文系统的过渡区带.

从 $2.5 \mathrm{~km}$ 向下为封闭性水文迟缓带, 处于异常高压系统内 ${ }^{[19-22]}$, 在该带矿化度、氯离子等物质含量 相对处于稳定高值, 矿化度高值保持在 $200 \mathrm{~g} / \mathrm{L}$, 氯离子、钙离子、钠离子等物质的量也保持相对高值状 态, 以 $\mathrm{CaCl}_{2}$ 水型为主, 同时发育部分 $\mathrm{NaHCO}_{3}$ 水型, 但 $\mathrm{NaHCO}_{3}$ 水型基本分布于低值的矿化度地层 水中, 反映了该带水交替活动很弱，水文活动迟缓，物质在该区得到聚集，是相对封闭的水文地质 系统.

表 1 东营凹陷古近系各水化学参数统计特征

Tab.1 Statistics of every hydrochemical parameters in the Paleogene System in Dongying sag

\begin{tabular}{|c|c|c|c|c|c|c|c|c|c|c|c|c|c|c|}
\hline \multirow[t]{2}{*}{ 层位 } & \multicolumn{2}{|c|}{$\begin{array}{c}\text { 矿化度 } \\
(\mathrm{g} / \mathrm{L}) \\
\end{array}$} & \multicolumn{2}{|l|}{$\begin{array}{c}\mathrm{Cl}^{-} \\
(\mathrm{g} / \mathrm{L}) \\
\end{array}$} & \multicolumn{2}{|l|}{$\begin{array}{l}\mathrm{Ca}^{2+} \\
(\mathrm{g} / \mathrm{L}) \\
\end{array}$} & \multicolumn{2}{|l|}{$\begin{array}{l}\mathrm{Na}^{+} \\
(\mathrm{g} / \mathrm{L}) \\
\end{array}$} & \multicolumn{2}{|l|}{$\begin{array}{c}\mathrm{HCO}_{3}^{-} \\
(\mathrm{g} / \mathrm{L}) \\
\end{array}$} & \multicolumn{2}{|l|}{$\begin{array}{l}\mathrm{SO}_{4}{ }^{2-} \\
(\mathrm{g} / \mathrm{L}) \\
\end{array}$} & \multicolumn{2}{|l|}{$\begin{array}{l}\mathrm{Mg}^{2+} \\
(\mathrm{g} / \mathrm{L}) \\
\end{array}$} \\
\hline & 分布范围 & 平均 & 分布范围 & 平均 & 分布范围 & 平均 & 分布范围 & 平均 & 分布范围 & 平均 & 分布范围 & 平均 & 分布范围 & 平均 \\
\hline Ek & $0.48-336.4$ & 60.6 & $0.125-209.6$ & 35.68 & $0.022-7.862$ & 3.566 & $0.551-33.35$ & 16.52 & $0.049-0.202$ & 0.117 & $0.051-2.604$ & 0.573 & $0.001-0.579$ & 0.303 \\
\hline $\mathrm{Es}_{4}{ }^{\mathrm{x}}$ & $1.63-335.5$ & 63.3 & $0.355-205.1$ & 37.84 & $0.021-19.37$ & 4.097 & $0.854-86.47$ & 29.08 & $0.05-3.03$ & 0.561 & $0.0048-98.34$ & 42.002 & $0.002-4.276$ & 0.502 \\
\hline $\mathrm{Es}{ }_{4}{ }^{\mathrm{s}}$ & $1.29-289.9$ & 54.2 & $0.416-177.51$ & 31.83 & $0.007-27.36$ & 3.883 & $0.554-96.96$ & 22.9 & $0.063-3.279$ & 0.967 & $0.005-3.343$ & 0.515 & $0.001-26.33$ & 0.764 \\
\hline $\mathrm{Es}_{3}{ }^{\mathrm{x}}$ & $2.304-303.3$ & 64.8 & $1.299-186.96$ & 39.02 & $0.093-60.06$ & 4.097 & $1.837-68.87$ & 21.12 & $0.098-2.694$ & 0.928 & $0.007-4.847$ & 0.596 & $0.006-14.74$ & 0.693 \\
\hline $\mathrm{Es}_{3}{ }^{2}$ & $1.26-330.8$ & 56.8 & $0.694-203.71$ & 32.72 & $0.002-19.87$ & 2.227 & $1.519-70.51$ & 17.07 & $0.013-5.003$ & 1.551 & $0.005-16.32$ & 0.609 & $0.002-1.341$ & 0.232 \\
\hline $\mathrm{Es}_{3}{ }^{\mathrm{s}}$ & $3.16-289.4$ & 42.4 & $0.558-168.97$ & 23.98 & $0.012-32.31$ & 3.572 & $1.007-69.23$ & 15.63 & $0.001-4.77$ & 1.291 & $0.012-6.798$ & 0.465 & $0.006-3.08$ & 0.421 \\
\hline $\mathrm{E} s_{2}$ & $0.18-261.8$ & 33.6 & $0.727-162.97$ & 20.27 & $0.022-15.63$ & 1.269 & $0.73-75.77$ & 10.83 & $0.057-4.424$ & 0.976 & $0.006-2.651$ & 0.272 & $0.006-1.299$ & 0.185 \\
\hline $\mathrm{E} s_{1}$ & $1.57-132.8$ & 20.9 & $0.248-79.89$ & 11.62 & $0.031-4.896$ & 0.722 & $1.299-45.01$ & 8.522 & $0.053-1.376$ & 0.411 & $0.002-1.093$ & 0.193 & $0.006-4.524$ & 0.418 \\
\hline Ed & $0.38-96.5$ & 17.7 & $0.747-58.17$ & 10.48 & $0.023-2.746$ & 0.693 & $1.143-34.03$ & 9.566 & $0.192-2.51$ & 0.869 & $0.007-10.37$ & 0.921 & $0.012-0.475$ & 0.135 \\
\hline
\end{tabular}

表2 东营凹陷古近系水化学比例参数及水型统计特征

Tab.2 Statistics of every hydrochemical parameters of ions composition in the Paleogene System in Dongying sag

\begin{tabular}{|c|c|c|c|c|c|c|c|c|c|c|c|c|}
\hline \multirow{2}{*}{ 层位 } & \multicolumn{2}{|c|}{ 变质系数 } & \multicolumn{2}{|c|}{ 氯镁系数 } & \multicolumn{2}{|c|}{ 碳酸盐平衡系数 } & \multicolumn{2}{|c|}{ 脱硫系数 } & \multicolumn{4}{|c|}{ 各水型百分含量(\%) } \\
\hline & 分布范围 & 平均 & 分布范围 & 平均 & 分布范围 & 平均 & 分布范围 & 平均 & $\mathrm{CaCl}_{2}$ & $\mathrm{NaHCO}_{3}$ & $\mathrm{MgCl}_{2}$ & $\mathrm{Na}_{2} \mathrm{SO}_{4}$ \\
\hline Ek & $0.515-0.747$ & 0.592 & $57.65-737$ & 195.92 & $0.016-2.227$ & 0.366 & $0.394-91.2$ & 9.06 & 80.4 & 15.7 & 3.9 & 3.9 \\
\hline $\mathrm{Es}_{4}{ }^{\mathrm{x}}$ & $0.444-1.988$ & 0.608 & $20.7-2388.3$ & 214.9 & $0.01-144.3$ & 5.176 & $0.01-161.7$ & 8.55 & 74.5 & 20.7 & 3.4 & 1.4 \\
\hline $\mathrm{Es}_{4}{ }^{\mathrm{s}}$ & $0.394-1.893$ & 0.671 & $5.453-1142.2$ & 185.3 & $0.007-138.1$ & 10.79 & $0.048-179.6$ & 7.37 & 84.3 & 12.5 & 1.3 & 1.9 \\
\hline $\mathrm{Es}_{3}{ }^{\mathrm{x}}$ & $0.015-0.859$ & 0.858 & $10.27-2619.8$ & 219.2 & $0.013-56.67$ & 4.282 & $0.018-40.79$ & 4.539 & 78.4 & 14.4 & 5.2 & 1.9 \\
\hline $\mathrm{Es}_{3}{ }^{\mathrm{z}}$ & $0.473-3.196$ & 0.768 & $25.35-2165$ & 250.1 & $0.013-351.3$ & 38.5 & $0.049-88.2$ & 6.689 & 64.2 & 33.2 & 1.9 & 0.6 \\
\hline $\mathrm{E} s_{3}{ }^{\mathrm{s}}$ & $0.354-1.042$ & 0.633 & $14.15-734.1$ & 185.9 & $0.0001-99.9$ & 15.15 & $0.089-16.2$ & 3.604 & 62.4 & 34.6 & 3 & 0 \\
\hline $\mathrm{E} s_{2}$ & $0.385-1.874$ & 0.654 & $46-561.1$ & 138.5 & $0.024-163.9$ & 11.24 & $0.012-49.67$ & 4.134 & 75.6 & 21.3 & 2.8 & 0.2 \\
\hline $\mathrm{E} s_{1}$ & $0.499-0.766$ & 0.615 & $8.543-662.7$ & 112.9 & $0.064-20.91$ & 3.13 & $0.009-155.2$ & 8.788 & 68.4 & 25.7 & 4.3 & 1.6 \\
\hline $\mathrm{Ed}$ & $0.585-0.803$ & 0.641 & $26.46-212.25$ & 121.05 & $0.392-38.87$ & 7.239 & $0.177-176.43$ & 16.49 & 64.6 & 20.8 & 0 & 4.2 \\
\hline
\end{tabular}




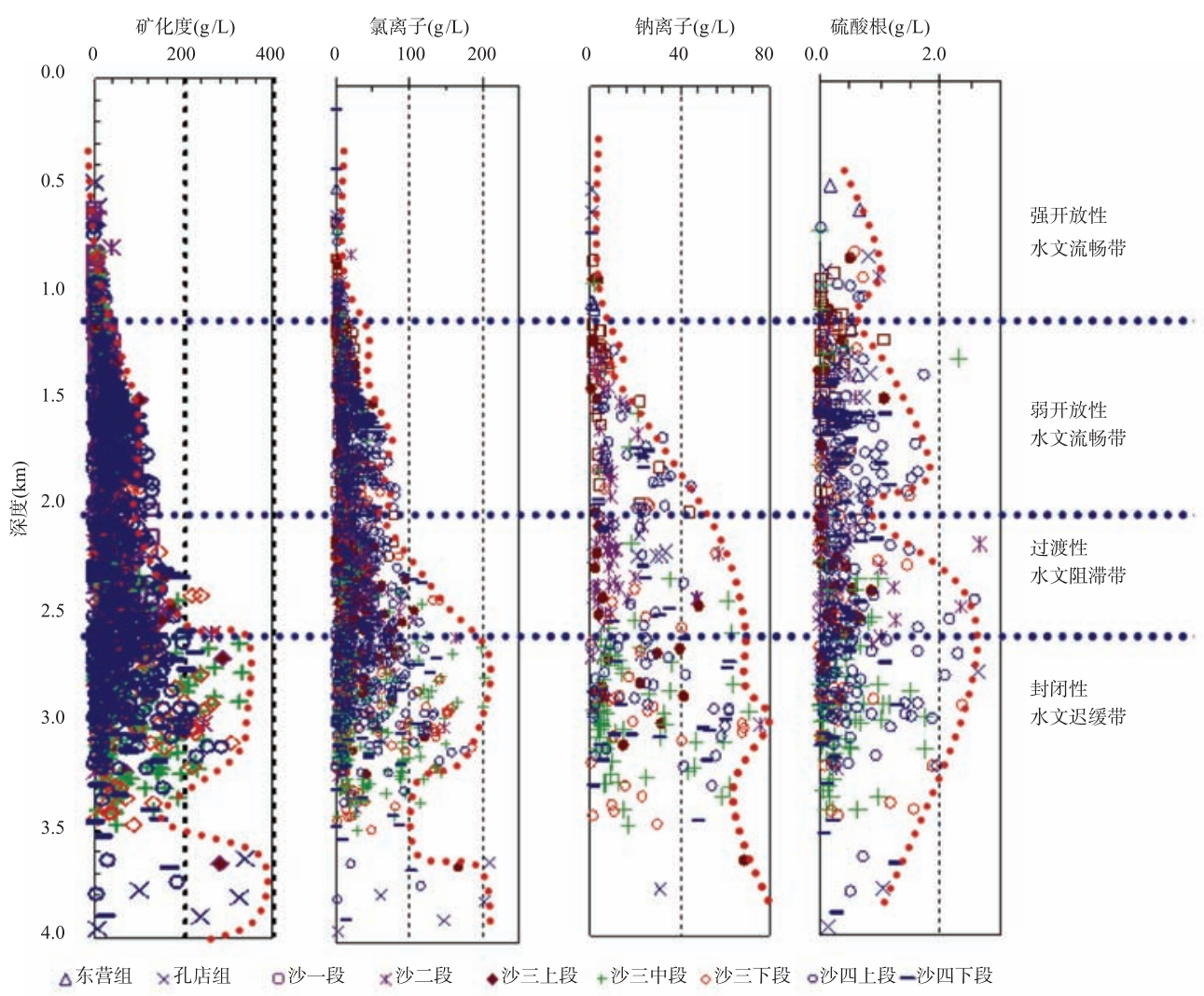

图3 东营凹陷古近系矿化度及离子含量剖面分布

Fig.3 The sectional distribution of total salinity and content of ions in the Paleogene System in Dongying sag

\section{4 结论}

以 $\mathrm{CaCl}_{2}$ 水型为主的高矿化度地层水是东营凹陷古近系咸化湖盆的典型响应特征. 伴随东营凹陷古 近系咸化湖盆向微咸化湖盆及淡水湖盆演化，出现矿化度、氯离子等相应减小的地球化学响应，其他水 化学参数也有着相应的地球化学响应.

东营凹陷古近系水化学剖面宏观上具有一定的分带性，大致可以划分为四种水文环境：以强开放性 水文流畅带(地表到 $1.1 \mathrm{~km})$ 、弱开放性水文流畅带 $(1.1-2.0 \mathrm{~km})$ 、水文阻滞过渡带 $(2.0-2.5 \mathrm{~km})$ 和封闭性水文 迟缓带 $(2.5 \mathrm{~km}$ 以下)水化学剖面的分带性与压力分布有着良好的对应关系.

东营凹陷古近系水化学场经历了早期的沉积与淋滤的交替和新生代的埋藏封闭作用期，其中在东营 运动时期古近系水化学场表现最为活跃，是深层卤水咸化地表浅层淡水从而使浅层出现高矿化度地层水 的关键作用期, 断裂的沟通起了重要作用, 显示出断陷湖盆的典型特征.

致谢: 感谢审稿专家及编辑部对本文提出的修改意见, 汪旭东同学协助绘制了部分图件，在此表示衰心 的感谢!

\section{5 参考文献}

[1] Chaudhuri S, Broedel V, Clauer N. Strontium isotopic evolution of oil-field waters from carbonate reservoir rocks in Bindley field, central Kansas, USA. Geochim Cosmochim Acta, 1987, 51: 45-53.

[2] Connolly CA, Walter LM, Baadsgaad H et al. Origin and evolution of formation waters, Albert Basin, Western Canada Sedimentary Basin: II . Isotope systematics and water mixing. Appl Geochem, 1990, 5: 397-413. 
[3] Moldovanyi EP, Walter LM, Land LS. Strontium, boron, oxygen and hydrogen isotope geochemistry of brines from basal strata of the Gulf Coast sedimentary basin, USA. Geochim Cosmochim Acta, 1993, 57: 2083-2099.

[4] Cai CF, Franks SG., Aagaard P. Origin and migration of brines from Paleozoic strata in Central Tarim, China: constraints from ${ }^{87} \mathrm{Sr} /{ }^{86} \mathrm{Sr}, \delta D, \delta^{18} \mathrm{O}$ and water chemistry. Applied Geochemistry, 2001, 16: 1269-1283.

[5] Wilson TP, Long DT. Geochemistryand isotope chemistry of Ca-Na-Cl brines in Silurian strata, Michigan Basin, U.S.A. Appl Geochem, 1993, 8: 507-522.

[6] Fisher JB, Boles JR. Water-rock interaction in Ternary sandstones, San Joaquim basin, California, USA: Diagenetic controls on water composition. Chem Geol, 1990, 82: 83-101.

[7] 查 明, 陈中红, 张年富等. 准噶尔盆地陆梁地区水化学特征与油气运聚. 地质科学, 2003, 38(3): 315-322.

[8] 张小莉, 查 明, 赫拴柱等. 渤海湾盆地廊固凹陷地层水化学纵向分带性与油气富集. 石油实验地质, 2006, 28(2): $87-190$.

[9] 楼章华, 金爱民, 朱 蓉等. 松辽盆地油田地下水化学场的垂直分带性与平面分区性. 地质科学, 2006, 41(3): 392-403.

[10] 金爱民, 高兴友, 楼章华等. 准噶尔盆地玛湖一盆 1 井西复合含油气系侏罗系地下水动力场的形成与演化. 地质科学, 2006, 41(4): 549-563.

[11] 于兴河, 姜 辉, 李胜利等. 中国东部中、新生代陆相断陷盆地沉积充填模式及其控制因素一以济阳坳陷东营凹陷为 例. 岩性油气藏, 2007, 19(1): 40-45.

[12] 朱光有, 金 强, 周建林等. 渤海湾盆地东营断陷湖盆充填模式研究. 石油实验地质, 2003, 25(2): 143-148.

[13] 朱光有, 金 强, 戴金星等. 东营凹陷沙四段中部盐湖相烃源岩研究. 高校地质学报, 2004, 10(2): 257-266.

[14] 姚益民, 徐金鲤, 单怀广等. 山东济阳坳陷早第三纪海侵的讨论. 石油学报, 1992, 13(2): 29-34.

[15] 袁 静, 覃 克. 东营凹陷沙四段深水成因蒸发岩特征及其与油气藏的关系. 石油大学学报, 2001, 25(1): 9-11,15.

[16] 金 强, 朱光有. 中国中新生代咸化湖盆烃源岩沉积的问题及相关进展. 高校地质学报, 2006, 12(4): 483-492.

[17] 陈中红，查 明. 东营凹陷波动古湖相烃源岩沉积特征. 湖泊科学, 2006, 18(1): 19-25.

[18] 刘 震, 许晓明, 谢启超等. 渤海湾盆地异常高压晚期形成特征分析. 现代地质, 2006, 20(2): 259-267.

[19] 刘晓峰, 解习农, 姜 涛等. 东营凹陷流体动力系统研究. 地质科技情报, 2006, 25(1): 55-59.

[20] 陈中红, 查 明. 东营凹陷流体超压封存箱与油气运聚. 沉积学报, 2006, 24(4): 607-613.

[21] 陈中红, 查 明. 东营凹陷超压系统的幕式排烃. 石油与天然气地质, 2004, 25(4): 445-447.

[22] 陈中红, 查 明. 东营凹陷烃源岩排烃的地质地球化学特征. 地球化学, 2005, 34(1): 79-86. 